\title{
Exploring the relationship between active bacterioplankton and phytoplankton in the Southern Ocean
}

\author{
E. Ortega-Retuerta ${ }^{1, *}$, I. Reche ${ }^{1,2}$, E. Pulido-Villena ${ }^{3}$, S. Agustí ${ }^{4}$, C. M. Duarte ${ }^{4}$ \\ ${ }^{1}$ Departamento de Ecología, Facultad de Ciencias, Universidad de Granada, 18071 Granada, Spain \\ ${ }^{2}$ Instituto del Agua, Universidad de Granada, 18071 Granada, Spain \\ ${ }^{3}$ Laboratoire d'Océanographie de Villefranche, Villefranche-sur-Mer, France \\ ${ }^{4}$ Institut Mediterrani d'Estudis Avançats (IMEDEA) (CSIC-UIB), Miquel Marqués 21, 07190 Esporles, Illes Balears, Spain
}

\begin{abstract}
Bacterioplankton are a heterogenous community composed of cells with different physiological states. The consideration of the active fraction of bacterioplankton as a potential factor affecting the strength of the relationship between bacteria and phytoplankton in the Southern Ocean was evaluated in waters around the Antarctic Peninsula. We estimated active bacterioplankton from uptake of ${ }^{3} \mathrm{H}$-Leucine (bacterial production [BP]) and using vital stains to estimate their proportion within the total bacterioplankton community, based on their relative nucleic acid content (high [HNA] vs. low [LNA]), and by nucleic acid double staining (NADS), based on their membrane permeability. Then we performed a comparative analysis between total and active bacterioplankton and chlorophyll $a(\mathrm{chl} a)$ in this area. Staining with NADS suggested that $61 \%$ of all bacteria were viable, a higher proportion of the total bacterial community than previously reported for the Southern Ocean. HNA bacteria comprised $45 \%$ of all bacteria, indicating that $16 \%$ of bacteria may be viable but with LNA. BP was more strongly related to abundance of LNA cells than NADS-viable or HNA bacteria. The relationship between chl $a$ and bacterial abundance (BA) did not increase when considering the abundance of HNA or NADS-viable cells alone, showing that viability/activity of stains did not enhance the linkage between BA and phytoplankton biomass in the Southern Ocean. In contrast, the relationship between $\mathrm{chl} a$ and BP was stronger than those reported in the literature, suggesting that, in this region, BP is closely dependent on phytoplankton.
\end{abstract}

KEY WORDS: Active bacteria - NADS - HNA - LNA - Bacterial production - Chlorophyll a Southern Ocean

Resale or republication not permitted without written consent of the publisher

\section{INTRODUCTION}

Aquatic bacterioplankton is strongly dependent on organic matter derived from phytoplankton (Cole et al. 1982). This dependence leads to the existence of a general relationship between phytoplankton biomass (as chlorophyll a) and bacterial biomass or between primary and bacterial production across broad-spectrum aquatic ecosystems (Cole et al. 1988, Gasol \& Duarte 2000).

In Southern Ocean waters, the absence of significant land inputs render bacteria strongly dependent on organic carbon released by algae (Morán et al. 2002). However, instead of an expectedly tight relationship between bacteria and phytoplankton (i.e. with a steeper slope than previously reported), different field and experimental studies have reported a weaker relationship between bacterioplankton (either abundance or biomass) and chlorophyll a (chl a) or primary production in this region (Bird \& Karl 1999, Duarte et al. 2005). This weaker relationship may be due to several non-exclusive explanations, such as losses due to predation by protists (Vaqué et al. 2002, Duarte et al. 2005), viral lysis infection (Guixa-Boixereu et al. 2002), or low temperatures which preclude an optimal assimilation of organic substrates (Pomeroy \& Wiebe 2001). In addition, the use of total bacteria presupposes that they are uniformly active and, thus, large numbers of 
inactive bacteria could mask the correlation between active bacteria and the substrate that supports them. Indeed, previous studies (Davidson et al. 2004, Pearce et al. 2007) have shown low fractions of active bacteria in the Southern Ocean. Hence, the unique consideration of the active fraction of the bacterial community could lead to a tighter relationship (i.e. higher slope) between bacterial abundance and chl a.

The estimates of the active fraction of the bacterial community are strongly dependent on the techniques used (Smith \& del Giorgio 2003). Single-cell methods such as microautoradiography or fluorescent in situ hybridization are considered very sensitive for enumerating metabolically active bacteria (Hoppe 1976, Karner \& Fuhrman 1997). On the other hand, flow cytometry, with nucleic acid stains such as SYTO 13, has been extensively used due to its simplicity and speed, which allows processing of a large number of samples. This technique has revealed the existence of bacterial subpopulations that differ considerably in the degree of staining and, therefore, in the nucleic acid content per cell, allowing classification of cells with relatively high (HNA) and low (LNA) nucleic acid content. The discrimination between HNA and LNA cells has been attributed to different phylogenetic compositions (Zubkov et al. 2001) or used as a proxy for active and non-active components of the bacterial community (Gasol et al. 1999). However, this simple, dichotomous classification has recently come into question (Sherr et al. 2006, Bouvier et al. 2007, Morán et al. 2007). Another easy and helpful technique is nucleic acid double staining (NADS), which is based on simultaneous staining with SYBR Green (staining all cells) and Propidium Iodide (PI, staining only membrane-damaged cells) (Barbesti et al. 2000) that allows discrimination of live (PI-impermeable) vs. dead (PI-positive) cells in natural assemblages (Grégori et al. 2001, Falcioni et al. 2008). Although some authors (Pirker et al. 2005) have found that PI-positive cells can also uptake organic substrates, the proportion of viable (PI-impermeable) cells could be considered an acceptable cutoff in the continuum from inactive to active cells.

In the present study, we determined the magnitude of the active fraction of bacterioplankton in the Southern Ocean using independent techniques in parallel, and we assessed its significance in affecting the relationship between bacteria and chl $a$ in waters around the Antarctic Peninsula.

\section{MATERIALS AND METHODS}

Study area and sampling. Sampling was carried out during January and February 2004 and 2005 in the 2 ICEPOS oceanographic cruises along the Antarctic Peninsula and Bransfield Strait (Fig. 1). The first cruise (ICEPOS 2004) took place from 14 January to 9 February 2004 aboard RV 'Las Palmas' and 12 stations were selected with 4 to 5 depths each, from surface waters to $150 \mathrm{~m}$. These stations covered 3 transects: from Livingstone Island to (1) Deception Island, (2) Anvers Island, and (3) King George Island (Fig. 1). The second cruise (ICEPOS 2005) took place aboard RV 'Hespérides' from 26 January to 26 February 2005. We selected 18 stations along the eastern Bellingshausen Sea, the Bransfield and Gerlache Straits and the western Weddell Sea (Fig. 1). At each station, 5 to 6 depths were sampled, from surface waters to mid-depth waters, generally 150 to $200 \mathrm{~m}$, below the deep chlorophyll maximum (DCM) located between 15 and $35 \mathrm{~m}$. Water was collected using a Niskin bottle with external spring (Ocean Test, 12 l) during ICEPOS 2004 and a Sea-Bird rossette sampler

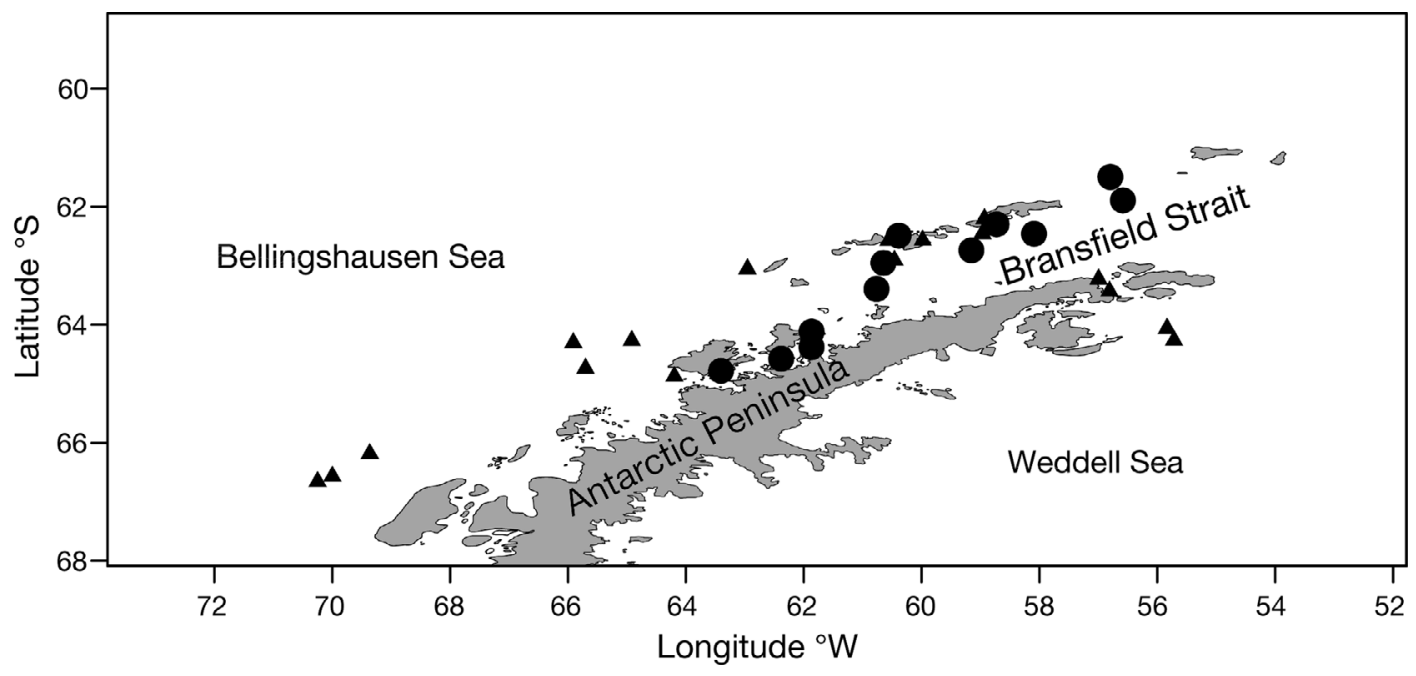

Fig. 1. Stations sampled during ICEPOS 2004 (•) and 2005 (A) cruises 
(24 Niskin bottles, 12 l each) attached to a conductivity/temperature/depth (CTD) system during ICEPOS 2005.

Total, HNA and LNA bacterial abundance. Total bacterial abundance (BA) samples were determined by epifluorescence microscopy (Porter \& Feig 1980) during the ICEPOS 2004 cruise. Water subsamples of 4 to $10 \mathrm{ml}$ were filtered through $0.2 \mu \mathrm{m}$ polycarbonate black filters and stained with DAPI $(4,6$-diamidino-2 phenylindole) to a final concentration of $1 \mu \mathrm{g} \mathrm{ml}^{-1}$. At least 350 cells in 15 random fields were counted per filter. During ICEPOS 2005, BA was determined by flow cytometry. Subsamples $(4 \mathrm{ml})$ were fixed with $1 \%$ paraformaldehyde, allowed 30 min to fix in the dark, deep frozen in liquid nitrogen and then stored frozen at $-70^{\circ} \mathrm{C}$ (Troussellier et al. 1995). Analyses were conducted within a maximum of $2 \mathrm{~d}$ from sample collection. The samples were thawed, a $400 \mu$ sample was stained with $4 \mu \mathrm{l}$ of $5 \mathrm{\mu mol} \mathrm{l}^{-1}$ SYTO13 (Molecular Probes) for $10 \mathrm{~min}$ in the dark, and run through a FACScalibur ${ }^{\mathrm{TM}}$ flow cytometer (BD Biosciences) fitted with a laser emitting at $488 \mathrm{~nm}$. Samples were run at a low flow rate and data were acquired in log mode until around 10000 events were acquired. A stock solution (5 $\mu \mathrm{l}$ ) of yellow-green $0.92 \mu \mathrm{m}$ Polysciences latex beads was added as an internal standard per $400 \mu \mathrm{l}$ of sample. The concentration of the fluorescent beads was calibrated twice during the cruise with TruCounts (Becton Dickinson). Bacteria were detected by their signature in bivariate plots of Side scatter (SSC) vs. FL1 (green fluorescence) and those with HNA or LNA discriminated by their green fluorescence. Data were gated and counted in the SSC vs. FL1 plot using the Paint-a-Gate software (del Giorgio et al. 1996a, Gasol \& del Giorgio 2000). HNA and LNA abundances were expressed in cells $\mathrm{ml}^{-1}$. HNA was also expressed as the percentage of the total bacteria counts ( $\%$ HNA).

Viable bacterial abundance. The Nucleic Acid Double Staining (NADS) flow cytometric protocol was used to quantify cell viability during ICEPOS 2005. This technique is based on the simultaneous use of 2 nucleic acid fluorescent dyes, SYBR Green I and Propidium Iodide (PI). Cell membranes are permeable to SYBR Green I irrespectively of cell viability. However, intact plasmic membranes characteristic of viable cells are impermeable to PI, thus staining with PI indicates compromised, damaged cells (Barbesti et al. 2000). Subsamples were analyzed immediately after collection. Samples $(400 \mu \mathrm{l})$ were simultaneously stained with $4 \mu \mathrm{l}$ of SYBR Green I (10-fold dilution of $10000 \times$ commercial solution [Molecular Probes] in dimethyl sulfoxide) and $4 \mu \mathrm{l}$ of Propidium iodide (PI, $1 \mathrm{mg} \mathrm{ml}^{-1}$ stock solution [Sigma]), reaching a final concentration of $10 \mu \mathrm{g}$ $\mathrm{ml}^{-1}$, and allowed to stain for $15 \mathrm{~min}$ in the dark. This final concentration is similar to the PI concentrations used and recommended as optimum in previous works (Falcioni et al. 2008). Samples were analyzed by flow cytometry. Bivariate plots of FL1 vs. FL2 (green vs. orange fluorescence, respectively) were obtained by flow cytometry to discriminate PI-impermeable bacteria (green fluorescent, hereafter referred to as viable cells) and PI-permeable bacteria (orange fluorescent) that appeared to have compromised cell membranes. Data were processed with Paint-a-Gate software. We expressed total viable cells in cells $\mathrm{ml}^{-1}$ and as a percentage of total BA counts determined with the protocol detailed above.

Bacterial production. Bacterial production (BP) was estimated during ICEPOS 2005 from ${ }^{3} \mathrm{H}$-Leucine-protein synthesis following the microcentrifugation technique proposed by Smith \& Azam (1992). Briefly, $5 \mu \mathrm{l}$ of $\mathrm{L}-\left[4,5-{ }^{3} \mathrm{H}\right]$ leucine was added to $1.5 \mathrm{ml}$ samples, yielding a final concentration of $52.7 \mathrm{nM}$, likely to be saturating in this region (Pedrós-Alió et al. 2002), and was incubated for 2 to $5 \mathrm{~h}$. We used a conversion factor from leucine to carbon incorporation of $1.5 \mathrm{~kg} \mathrm{C} \mathrm{mol}$ leu ${ }^{-1}$, which represents a standard, assuming no isotope dilution (Simon \& Azam 1989).

Chlorophyll a. Chl a concentration was determined fluorometrically by filtering $50 \mathrm{ml}$ subsamples through $25 \mathrm{~mm}$ Whatman GF/F filters, extracted into $10 \mathrm{ml}$ of $90 \%$ acetone for ca. $24 \mathrm{~h}$ in the dark and at $4{ }^{\circ} \mathrm{C}$. The fluorescence of the extracts was read in a previously calibrated Turner Design fluorometer (Parsons et al. 1984).

\section{RESULTS}

Total BA showed an average value of $5.9 \pm 0.9 \times 10^{5}$ cells ml ${ }^{-1}$ during ICEPOS 2004 and $7.2 \pm 0.5 \times 10^{5}$ cells $\mathrm{ml}^{-1}$ during ICEPOS 2005. During ICEPOS 2004, total BA ranged from 1.7 to $8.94 \times 10^{5}$ cells ml $^{-1}$ in surface waters and from 1.03 to $3.79 \times 10^{5}$ cells ml ${ }^{-1}$ in waters at $150 \mathrm{~m}$. During ICEPOS 2005, BA ranged from 2.0 to $16.3 \times 10^{5}$ cells ml ${ }^{-1}$ in surface waters and from 0.7 to $15.4 \times 10^{5}$ cells $\mathrm{ml}^{-1}$ in waters below the DCM. In ICEPOS 2004, total BA generally decreased with depth (9 of 12 stations) and the highest values were observed inside Port Foster in Deception Island. In 2005, total BA generally decreased with depth (10 stations, Fig. 2a), except in some particular stations where the vertical BA distribution was quite homogeneous (Fig. 2b). The highest total BA values were observed in the stations located in the Weddell Sea (Fig. 2c).

The abundance of HNA cells ranged one order of magnitude. The mean value was $3.0 \pm 0.2 \times 10^{5}$ cells $\mathrm{ml}^{-1}$, from 0.9 to $9.4 \times 10^{5}$ cells $\mathrm{ml}^{-1}$ in surface waters and from 0.52 to $5.71 \times 10^{5}$ cells ml ${ }^{-1}$ in waters below the DCM, showing a similar decreasing pattern with 

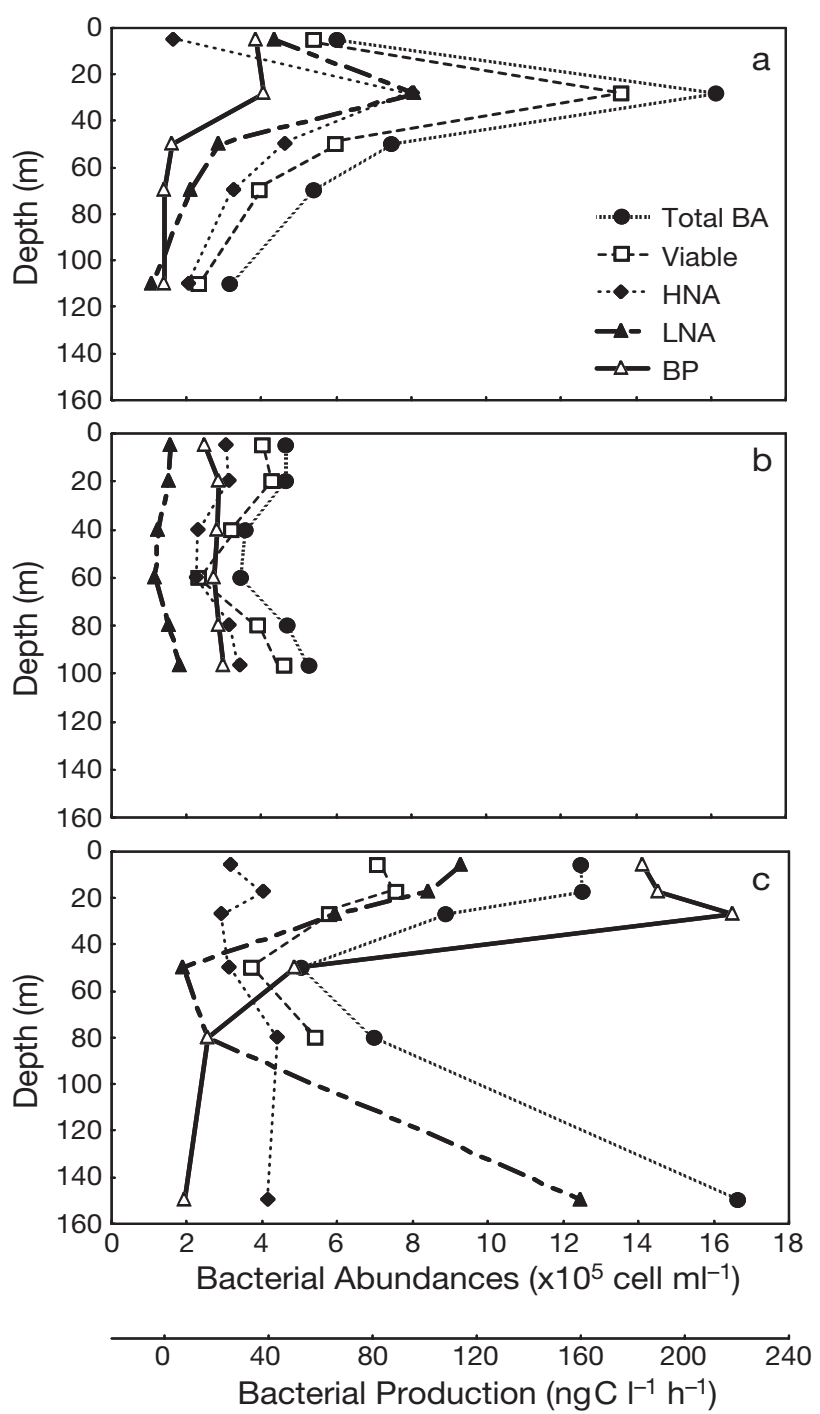

Fig. 2. Vertical profiles of total bacterial abundance (BA), viable cell abundance (Viable), high nucleic acid cell abundance (HNA), low nucleic acid cell abundance (LNA) and bacterial production (BP) in ICEPOS 2005, showing (a) the most common decreasing pattern (Stn 3, Bellingshausen Sea), (b) an exceptionally homogeneous distribution (Stn 8, Antarctic Strait) and (c) particularly high BP values (Stn 9, western Weddell Sea) depth as total BA, although this pattern was less accentuated (Fig. 2a). The percentage of HNA cells with respect to total BA generally increased over depth, ranging from $32 \pm 4 \%$ in surface waters to $52 \pm 4 \%$ in waters below the DCM. This HNA percentage was significant and negatively related to depth ( $\mathrm{r}=-0.44$, $\mathrm{p}<0.001, \mathrm{n}=77$ ). Total BA was correlated to HNA cells $(\mathrm{r}=0.86)$, but the proportion of HNA cells decreased as total BA increased (Table 1). The abundance of LNA cells showed a mean value of $4.1 \pm 0.4 \times 10^{5}$ cells ml $^{-1}$ and a wider range than HNA, from 0.6 to $9.5 \times 10^{5}$ cells $\mathrm{ml}^{-1}$ in surface waters and from 0.2 to $7.5 \times 10^{5}$ cells $\mathrm{ml}^{-1}$ in waters below the DCM.

Viable cells after NADS protocol showed a mean value of $4.6 \pm 0.4 \times 10^{5}$ cells ml $^{-1}$ and also ranged one order of magnitude, from 2.0 to $10.0 \times 10^{5}$ cells ml ${ }^{-1}$ in surface water samples and from 0.3 to $9.9 \times 10^{5}$ cells $\mathrm{ml}^{-1}$ in waters below the DCM. Viable cells comprised between 38 and $80 \%$ of total BA, generally exceeding the percentage of HNA cells, which indicates that a significant fraction of LNA cells were also viable (Fig. 3). The abundance of viable cells was also correlated to total BA $(r=0.94)$, but the proportion of viable cells was independent of the total BA $(r=-0.01)$ (Table 1)

BP showed a similar vertical pattern as total BA, with the lowest values below DCM (13 of 18 stations, Fig. 2a). The BP values ranged 2 orders of magnitude, from 2.0 to $183.8 \mathrm{ng} \mathrm{C}^{-1} \mathrm{~h}^{-1}$ in surface waters and from

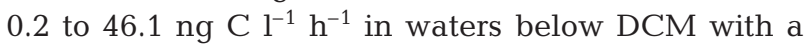

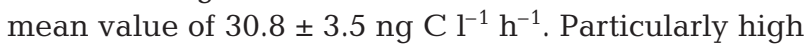
$\mathrm{BP}$ values were observed at the surface waters of the western Weddell Sea (Fig. 2c). BP and total BA were significant and positively correlated (Table 1). BP was also significant and positively correlated to HNA, LNA and viable cells, but this correlation coefficient was higher with LNA cells (Table 1).

Significant and positive relationships between BA and chl a concentration were observed in both ICEPOS 2004 and 2005 cruises. Although both regression slopes were lower than 0.4 , it was slightly higher for ICEPOS 2005 than for ICEPOS 2004 (Table 2, Fig. 4a).

Table 1. Correlation matrix among all bacterial variables determined during ICEPOS 2005. See Fig. 2 for abbreviations. ${ }^{*}$ Significant correlations $(\mathrm{p}<0.05)$

\begin{tabular}{|c|c|c|c|c|c|c|c|}
\hline $\mathrm{n}=63$ & $\begin{array}{c}\text { Total BA } \\
\left(\text { cell } \mathrm{ml}^{-1}\right)\end{array}$ & $\begin{array}{c}\text { Viable } \\
\left(\text { cell ml } \mathrm{m}^{-1}\right)\end{array}$ & $\begin{array}{l}\text { Percent } \\
\text { viable }\end{array}$ & $\begin{array}{c}\text { HNA } \\
(\text { cell ml-1) }\end{array}$ & $\begin{array}{c}\text { LNA } \\
\left(\text { cell ml }{ }^{-1}\right)\end{array}$ & $\begin{array}{c}\text { Percent } \\
\text { HNA }\end{array}$ & $\begin{array}{c}\mathrm{BP} \\
\left(\mathrm{ngC} \mathrm{l}^{-1} \mathrm{~h}^{-1}\right)\end{array}$ \\
\hline $\mathrm{BP}\left(\mathrm{ngC} \mathrm{l}^{-1} \mathrm{~h}^{-1}\right)$ & $0.71^{*}$ & $0.66^{*}$ & -0.02 & $0.50^{*}$ & $0.75^{*}$ & $-0.54^{*}$ & 1.00 \\
\hline Percent HNA & $-0.46^{*}$ & $-0.26^{*}$ & $0.47^{*}$ & 0.05 & $-0.69^{*}$ & 1.00 & \\
\hline LNA (cell ml ${ }^{-1}$ ) & $0.96^{*}$ & $0.85^{*}$ & -0.14 & $0.69^{*}$ & 1.00 & & \\
\hline HNA (cell ml ${ }^{-1}$ ) & $0.86^{*}$ & $0.92^{*}$ & $0.29^{*}$ & 1.00 & & & \\
\hline Percent viable & -0.01 & $0.34^{*}$ & 1.00 & & & & \\
\hline Viable $\left(\right.$ cell ml${ }^{-1}$ ) & $0.94^{*}$ & 1.00 & & & & & \\
\hline Total BA (cell ml ${ }^{-1}$ ) & 1.00 & & & & & & \\
\hline
\end{tabular}


Table 2. Relationships between chl a and all bacterial parameters (BA for each cruise, as well as total HNA, total LNA, total viable and BP for ICEPOS 2005). See Fig. 2 for abbreviations

\begin{tabular}{|c|c|c|c|c|c|c|}
\hline Cruise & Parameter (vs. chl a) & Slope $( \pm \mathrm{SE})$ & Intercept & $\mathrm{r}$ & $\mathrm{p}$ & $\mathrm{n}$ \\
\hline ICEPOS 2004 & Total BA & $0.291 \pm 0.053$ & 5.56 & 0.650 & $<0.001$ & 50 \\
\hline \multirow[t]{5}{*}{ ICEPOS 2005} & Total BA & $0.394 \pm 0.049$ & 5.79 & 0.681 & $<0.001$ & 78 \\
\hline & Viable & $0.414 \pm 0.057$ & 5.58 & 0.678 & $<0.001$ & 64 \\
\hline & HNA & $0.280 \pm 0.054$ & 5.41 & 0.512 & $<0.001$ & 76 \\
\hline & LNA & $0.505 \pm 0.059$ & 5.52 & 0.708 & $<0.001$ & 76 \\
\hline & $\mathrm{BP}$ & $0.870 \pm 0.068$ & 1.26 & 0.787 & $<0.001$ & 102 \\
\hline
\end{tabular}

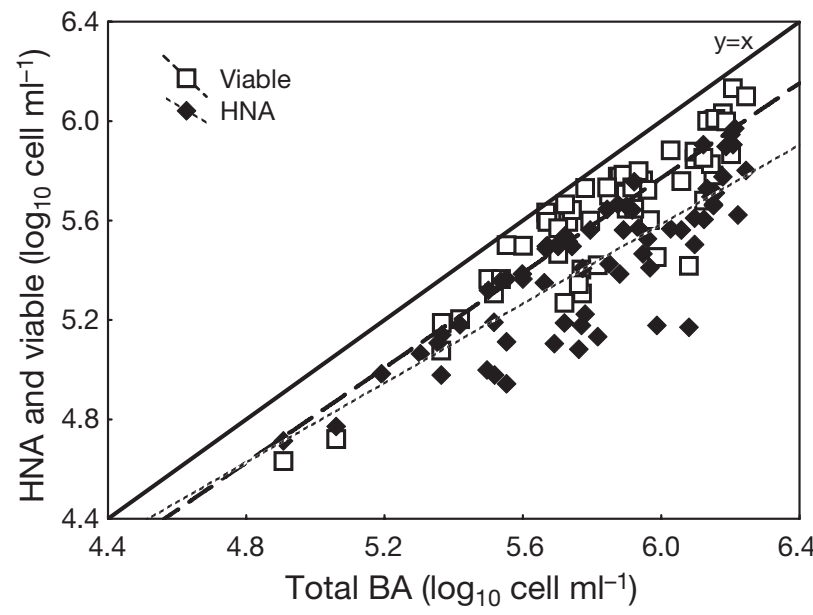

Fig. 3. Scatterplot between total BA and HNA and viablecells. Correlation coefficients are presented in Table 1. See Fig. 2 for abbreviations

All metrics of bacterial abundance (HNA, LNA and viable cells) and BP were significantly correlated with chl a in ICEPOS 2005 (Table 2, Fig. 4). A strong relationship was observed between chl $a$ and BP, with a log-log regression slope of 0.87 (Table 2). However, lower log-log slopes and correlation coefficients were observed between bacterial abundances and chl a. The relationship between viable cells and chl a did not show a significantly higher slope than that corresponding to total bacterial abundance (Table 2, Fig. 4). Surprisingly, the relationship between LNA cells and chl a showed a significantly higher slope than the slope with HNA cells (Statistica homogeneity-of-slopes model, $\mathrm{p}<0.01$ ) (Table 2, Fig. 4).

\section{DISCUSSION AND CONCLUSIONS}

Our results suggest that viable cells after NADS protocol represent an upper limit with respect to HNA cells (Fig. 3), as the proportion of viable (PI-impermeable) cells (61\%) exceeded that of HNA cells $(48 \%)$, indicating that there are viable bacteria with low acid nucleic content. This high concentration of viable cells observed in our study, although consistent with other published studies in natural waters (Schumann et al. 2003, Falcioni et al. 2008), contrasts with the only 2 reported studies that use PI stain to measure bacterial viability in the Southern Ocean (Davidson et al. 2004, Pearce et al. 2007), which reported considerably lower proportions (between 2 and $40 \%$ ). In the work of Pearce et al. (2007), the percentage of viable cells was likely underestimated as higher abundance of total bacteria were observed compared to the sum of viable and non-viable cells. By contrast, in the present study the percentage of viable cells (immediately analyzed with NADS protocol) with respect to total BA cells (previously fixed and stored) would result in an overestimation of viable cells since a potential loss of cell detection has been observed during storage (Kamiya et al. 2007). However, the potential error in the present study is expected to be minimal due to the short timelag (up to $2 \mathrm{~d}$ ) between fixation and analysis.

Total BA, HNA cells and BP obtained in this study were also comparable to those previously reported for the same area (Pedrós-Alió et al. 2002, Vaqué et al. 2002, Corzo et al. 2005) and elsewhere in the Southern Ocean (Ducklow et al. 2000, Granéli et al. 2004). The observed increase in percentage of HNA cells with depth could be explained by selective impact of bacterial grazers. HNA bacteria appear to be preferentially consumed by grazers, whereas LNA escape grazing pressure and will remain abundant (del Giorgio et al. 1996b). Only below the euphotic zone, where the grazing pressure decreases (Vaqué et al. 2002), can HNA bacteria comprise a large proportion of the total bacterial abundance (Jochem 2001, Corzo et al. 2005).

Since ${ }^{3} \mathrm{H}$-Leucine incorporation is a bulk measurement of heterotrophic activity, we expected the active fraction of bacterioplankton (either HNA cells or viable cells) to be more closely related to BP than to total BA, which includes bacteria that make little or no contribution to activity. Indeed, some authors (Gasol et al. 1999, Lebaron et al. 2001) have proposed that HNA cells dominate overall bacterial metabolism. However, in the present study LNA cells were more closely related to BP than HNA cells (Table 1, Fig. 4), indicating that 

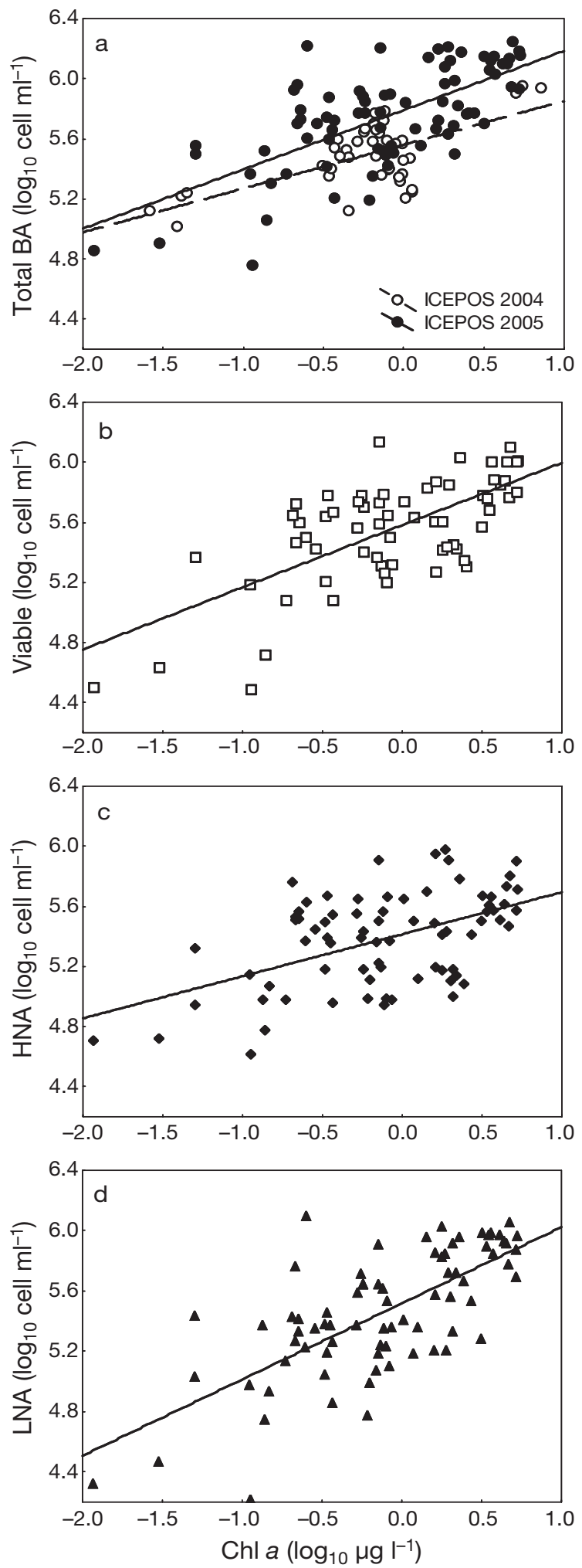

Fig. 4. Scatterplots and regression lines between chl a $\left(\mu \mathrm{g} \mathrm{l}^{-1}\right)$ and (a) total BA (cell $\mathrm{ml}^{-1}$ ) in both ICEPOS cruises, and (b) viable, (c) HNA and (d) LNA cells (cell ml ${ }^{-1}$ ) in ICEPOS 2005. Values for slopes, intercepts, correlation coefficients and levels of significance are presented in Table 2. See Fig. 2 for abbreviations the discrimination between high and low relative nucleic acid content is not a reliable proxy for the active vs. inactive fractions of the bacterioplankton, supporting recent observations along this line (Sherr et al. 2006). Other studies (Zubkov et al. 2001, Longnecker et al. 2005) also found that LNA cells are responsible for similar or higher fractions of total leucine incorporation than HNA cells in low-chlorophyll waters. Hence, our results corroborate that the simplistic interpretation of HNA and LNA cells as active and inactive subpopulations is also unreliable in Antarctic waters. Rather than differences in activity, HNA and LNA subpopulations appear to represent different fractions with intrinsic properties (e.g. phylogenetically distinct subpopulations), and these fractions may be dynamically linked, with the capacity of LNA cells to shift to HNA and vice versa (Bouvier et al. 2007). In addition, the discrimination of viable cells did not result in a higher correlation with bacterial production (Table 1), as expected from previous reports (Pearce et al. 2007, Falcioni et al. 2008). Like Pirker et al. (2005), our study showed that the PI stain is not the most reliable method of examining bacterial activity in the field.

There is still a debate about the estimation of active and viable bacterioplankton, which is in part semantic (e.g. actively growing cells, viable but inactive cells with potential activity, inactive and dead cells), but reflects the absence of a widely accepted standard technique. Active bacteria have been determined using a panoply of different techniques yielding divergent estimates (Berman et al. 2001, Schumann et al. 2003, Smith \& del Giorgio 2003). Hence, low proportions of activity $(<10$ to $20 \%)$ have been reported, based on the presence of a nucleoid (Berman et al. 2001, Luna et al. 2004) or actively respiring the fluorogenic tetrazolium dye, 5-cyano-2,3 ditolyl tetrazolium chloride (Karner \& Fuhrman 1997, Berman et al. 2001), while single-cell approaches, such as fluorescent in situ hybridization or microautoradiography, have yielded higher proportions of active cells (Smith \& del Giorgio 2003). In comparison, the discrimination of viable bacteria based on their membrane integrity using PI, To-Pro or SYTOX staining, Live/Dead BacLight $^{\mathrm{TM}}$ or NADS protocol (Boulos et al. 1999, Davidson et al. 2004, Luna et al. 2004), or active bacteria based on their relative nucleic acid content (HNA vs. LNA; Gasol et al. 1999, Corzo et al. 2005) shows widely variable proportions of active cells. Indeed, this lack of agreement between bacterial activity estimates reflects a continuum of bacterial metabolic states in contrast to the simplistic restriction to discrete categories as active or inactive, and it is unlikely that a single method can capture all the physiological diversity present in bacterioplankton assemblages. 
Our aim to assess whether the contribution of specific subpopulations could explain the weak relationship between chl $a$ and bacteria found in Antarctic waters gave impetus to discriminating active from inactive bacteria. However, the discrimination of HNA or viable cells within the total abundance in ICEPOS 2005 did not lead to steeper regression slopes or stronger correlation coefficients than the relationship between chl $a$ and total BA (Table 2, Fig. 4). This relationship only improved, unexpectedly, when considering LNA cells (Table 2, Fig. 4). Unlike the lower slope observed in the log-log relationship between total BA and chl a (slope $=0.3$ to 0.4 in comparison to the value of 0.52 reported by Cole et al. [1988]), the slope of the log-log relationship between BP and chl a concentration (0.87) was even steeper in the Antarctic communities examined than that in the general relationship (0.62) reported by Cole et al. (1988), and consistent with previous reports of stronger relationships between chl $a$ and BP than with BA in the Southern Ocean (Granéli et al. 2004, Duarte et al. 2005). Indeed, previous studies have observed a close coupling between dissolved primary production, a more direct surrogate of algal derived substrates, and bacterial carbon demand in Antarctic waters (Morán et al. 2002), suggesting that in this area bacteria are tightly dependent on algal organic carbon for growth and metabolism, but this dependence is not reflected in terms of total BA, HNA or viable cells. These results suggest that cell abundance was generally more constrained than bacterial protein synthesis, resulting in a significantly steeper slope value for the chl a-BP relationship and lower slopes in all the relationships with bacterial abundances. Indeed, the tight trophic linkage between protistan grazers and their prey (Bird \& Karl 1999, Vaqué et al. 2002, Duarte et al. 2005), or losses due to viral lysis (Guixa-Boixereu et al. 2002), may preclude significant changes in bacterial abundance, particularly in those cells with high relative nucleic acid (HNA), that appear to be preferentially predated upon. In contrast, protein synthesis usually increases more rapidly than cell duplication to maximize survival, particularly under unfavorable environmental conditions (Ducklow et al. 1992).

In summary, the results of this study revealed a high proportion of viable bacteria in the study area, and the active nature of LNA cells is evidenced by a closer relationship with BP than HNA or viable cells. In addition, although a close relationship between chl $a$ and BP was observed, the discrimination between HNA or viable cells from total BA did not result in a stronger relationship between chl $a$ and BA in the Southern Ocean, where bacterial abundance may be closely controlled by loss processes rather than resource supply.
Acknowledgements. We thank the crew of the RVs 'Las Palmas' and 'Hespérides' and the Marine Technology Unit for their help and technical assistance, and J.M. Gasol for his help in flow cytometric analyses. We also thank J.M. Gasol and 3 anonymous reviewers for their valuable comments on a previous version of this manuscript. This work was supported by grant REN2002-04165 from the Spanish National Research Program in Antarctica.

\section{LITERATURE CITED}

Barbesti S, Citterio S, Labra M, Baroni MD, Neri MG, Sgorbati S (2000) Two and three-color fluorescence flow cytometric analysis of immunoidentified viable bacteria. Cytometry 40:214-218

Berman T, Kaplan B, Chava S, Viner Y, Sherr BF, Sherr EB (2001) Metabolically active bacteria in Lake Kinneret. Aquat Microb Ecol 23:213-224

Bird DF, Karl DM (1999) Uncoupling of bacteria and phytoplankton during the austral spring bloom in Gerlache Strait, Antarctic Peninsula. Aquat Microb Ecol 19:13-27

> Boulos L, Prévost M, Barbeau B, Coallier J, Desjardins R (1999) LIVE/DEAD (R) BacLight (TM): application of a new rapid staining method for direct enumeration of viable and total bacteria in drinking water. J Microbiol Methods 37:77-86

Bouvier T, del Giorgio PA, Gasol JM (2007) A comparative study of the cytometric characteristics of high and low nucleic-acid bacterioplankton cells from different aquatic ecosystems. Environ Microbiol 9:2050-2066

Cole JJ, Likens GE, Strayer DL (1982) Photosynthetically produced dissolved organic-carbon: an important carbon source for planktonic bacteria. Limnol Oceanogr 27: 1080-1090

Cole JJ, Findlay S, Pace ML (1988) Bacterial production in fresh and saltwater ecosystems: a cross-system overview. Mar Ecol Prog Ser 43:1-10

> Corzo A, Rodríguez-Gálvez S, Lubián L, Sobrino C, Sangrá P, Martínez A (2005) Antarctic marine bacterioplankton subpopulations discriminated by their apparent content of nucleic acids differ in their response to ecological factors. Polar Biol 29:27-39

Davidson AT, Thomson PG, Westwood K, van den Enden R (2004) Estimation of bacterioplankton activity in Tasmanian coastal waters and between Tasmania and Antarctica using stains. Aquat Microb Ecol 37:33-45

del Giorgio PA, Bird DF, Prairie YT, Planas D (1996a) Flow cytometric determination of bacterial abundance in lake plankton with the green nucleic acid stain SYTO 13. Limnol Oceanogr 41:783-789

del Giorgio PA, Gasol JM, Vaqué D, Mura P, Agustí S, Duarte CM (1996b) Bacterioplankton community structure: protists control net production and the proportion of active bacteria in a coastal marine community. Limnol Oceanogr 41:1169-1179

Duarte CM, Agustí S, Vaqué D, Agawin NSR, Felipe J, Casamayor EO, Gasol JM (2005) Experimental test of bacteria-phytoplankton coupling in the Southern Ocean. Limnol Oceanogr 50:1844-1854

> Ducklow HW, Kirchman DL, Quinby HL (1992) Bacterioplankton cell-growth and macromolecular-synthesis in seawater cultures during the North Atlantic spring phytoplankton bloom, May, 1989. Microb Ecol 24:125-144

Ducklow HW, Dickson ML, Kirchman DL, Steward G, Orchardo J, Marra J, Azam F (2000) Constraining bacterial production, conversion efficiency and respiration in the 
Ross Sea, Antarctica, January-February, 1997. Deep-Sea Res II 47:3227-3247

Falcioni T, Papa S, Gasol JM (2008) Evaluating the flow-cytometric nucleic acid double-staining protocol in realistic situations of planktonic bacterial death. Appl Environ Microbiol 74:1767-1779

Gasol JM, del Giorgio PA (2000) Using flow cytometry for counting natural planktonic bacteria and understanding the structure of planktonic bacterial communities. Sci Mar 64:197-224

Gasol JM, Duarte CM (2000) Comparative analyses in aquatic microbial ecology: How far do they go? FEMS Microbiol Ecol 31:99-106

- Gasol JM, Zweifel UL, Peters F, Fuhrman JA, Hagström Å (1999) Significance of size and nucleic acid content heterogeneity as measured by flow cytometry in natural planktonic bacteria. Appl Environ Microbiol 65: 4475-4483

Granéli W, Carlsson P, Bertilsson S (2004) Bacterial abundance, production and organic carbon limitation in the Southern Ocean $\left(39-62^{\circ} \mathrm{S}, 4-14^{\circ} \mathrm{E}\right)$ during the austral summer 1997/1998. Deep-Sea Res II 51:2569-2582

> Grégori G, Citterio S, Ghiani A, Labra M, Sgorbati S, Brown S, Denis M (2001) Resolution of viable and membrane-compromised bacteria in freshwater and marine waters based on analytical flow cytometry and nucleic acid double staining. Appl Environ Microbiol 67:4662-4670

- Guixa-Boixereu N, Vaqué D, Gasol JM, Sanchez-Cámara J, Pedrós-Alió C (2002) Viral distribution and activity in Antarctic waters. Deep-Sea Res II 49:827-845

Hoppe HG (1976) Determination and properties of actively metabolizing heterotrophic bacteria in the sea, investigated by means of micro-autoradiography. Mar Biol 36:291-302

Jochem FJ (2001) Morphology and DNA content of bacterioplankton in the northern Gulf of Mexico: analysis by epifluorescence microscopy and flow cytometry. Aquat Microb Ecol 25:179-194

Kamiya E, Izumiyama S, Nishimura M, Mitchell JG, Kogure K (2007) Effects of fixation and storage on flow cytometric analysis of marine bacteria. J Oceanogr 63:101-112

Karner M, Fuhrman JA (1997) Determination of active marine bacterioplankton: a comparison of universal 16S rRNA probes, autoradiography, and nucleoid staining. Appl Environ Microbiol 63:1208-1213

> Lebaron P, Servais P, Agogue H, Courties C, Joux F (2001) Does the high nucleic acid content of individual bacterial cells allow us to discriminate between active cells and inactive cells in aquatic systems? Appl Environ Microbiol 67:1775-1782

Longnecker K, Sherr BF, Sherr EB (2005) Activity and phylogenetic diversity of bacterial cells with high and low nucleic acid content and electron transport system activity in an upwelling ecosystem. Appl Environ Microbiol 71:7737-7749

Luna GM, Dell'Anno A, Giuliano L, Danovaro R (2004) Bacterial diversity in deep Mediterranean sediments: relationship with the active bacterial fraction and substrate avail-

Editorial responsibility: Josep Gasol,

Barcelona, Spain ability. Environ Microbiol 6:745-753

> Morán XAG, Estrada M, Gasol JM, Pedrós-Alió C (2002) Dissolved primary production and the strength of phytoplankton-bacterioplankton coupling in contrasting marine regions. Microb Ecol 44:217-223

> Morán XAG, Bode A, Suárez LA, Nogueira E (2007) Assessing the relevance of nucleic acid content as an indicator of marine bacterial activity. Aquat Microb Ecol 46:141-152

Parsons TR, Maita Y, Lalli CM (1984) A manual of chemical and biological methods for seawater analysis. Pergamon Press, Oxford

Pearce I, Davidson AT, Bell EM, Wright S (2007) Seasonal changes in the concentration and metabolic activity of bacteria and viruses at an Antarctic coastal site. Aquat Microb Ecol 47:11-23

> Pedrós-Alió C, Vaque D, Guixa-Boixereu N, Gasol JM (2002) Prokaryotic plankton biomass and heterotrophic production in western Antarctic waters during the 1995-1996 Austral summer. Deep-Sea Res II 49:805-825

> Pirker H, Pausz C, Stoderegger KE, Herndl GJ (2005) Simultaneous measurement of metabolic activity and membrane integrity in marine bacterioplankton determined by confocal laser-scanning microscopy. Aquat Microb Ecol 39:225-233

Pomeroy LR, Wiebe WJ (2001) Temperature and substrates as interactive limiting factors for marine heterotrophic bacteria. Aquat Microb Ecol 23:187-204

Porter KG, Feig YS (1980) The use of DAPI for identifying and counting aquatic microflora. Limnol Oceanogr 25:943-948

> Schumann R, Schiewer U, Karsten U, Rieling T (2003) Viability of bacteria from different aquatic habitats. II. Cellular fluorescent markers for membrane integrity and metabolic activity. Aquat Microb Ecol 32:137-150

Sherr EB, Sherr BF, Longnecker K (2006) Distribution of bacterial abundance and cell-specific nucleic acid content in the Northeast Pacific Ocean. Deep-Sea Res I 53:713-725

Simon M, Azam F (1989) Protein content and protein synthesis rates of planktonic marine bacteria. Mar Ecol Prog Ser 51:201-213

Smith DC, Azam F (1992) A simple economical method for measuring bacterial protein synthesis rates in seawater using ${ }^{3} \mathrm{H}$ leucine. Mar Microb Food Webs 6:107-114

Smith EM, del Giorgio PA (2003) Low fractions of active bacteria in natural aquatic communities? Aquat Microb Ecol 31:203-208

Troussellier M, Courties C, Zettelmaier S (1995) Flow cytometric analysis of coastal lagoon bacterioplankton and picophytoplankton: fixation and storage effects. Estuar Coast Shelf Sci 40:621-633

> Vaqué D, Guixa-Boixereu M, Gasol JM, Pedrós-Alió C (2002) Distribution of microbial biomass and importance of protists in regulating prokaryotic assemblages in three areas close to the Antarctic Peninsula in spring and summer 1995/96. Deep-Sea Res II 49:847-867

Zubkov MV, Fuchs BM, Burkill PH, Amann R (2001) Comparison of cellular and biomass specific activities of dominant bacterioplankton groups in stratified waters of the Celtic Sea. Appl Environ Microbiol 67:5210-5218

Submitted: September 7, 2007; Accepted: May 29, 2008 Proofs received from author(s): June 2, 2008 